\title{
Modern Technology of Storage of Plant Products in the Food Industry
}

\author{
Zh B. Kaldybekova ${ }^{\# 1}$, Kulash K. Syrmanova ${ }^{* 1,2}$, Barna M. Khamitova ${ }^{\# 1}$, \\ Aibala R.Taspoltayeva ${ }^{\# 1}$, Aisulu S. Ungarbaeva ${ }^{* 2}$ \\ ${ }^{1}$ Auezov South Kazakhstan State University, Kazakhstan,160012, Shymkent, Tauke Khan av., 5 \\ zkaldybekova@mail.ru \\ syrmanova.kulash@mail.ru \\ barno-007@mail.ru \\ aibala.taspoltaeva.69@mail.ru \\ 2 "MIRAS" University, Kazakhstan, 160012, Shymkent, Ilyaevst., 3 \\ syrmanova.kulash@mail.ru \\ ungarbaeva.aisulu@mail.ru
}

Abstract-The preservation and maintenance of the quality of fruits and vegetables is becoming an increasingly important task and does not lose its relevance. The market demand for fresh fruits and vegetables of excellent quality is constantly growing. The main task of modern agricultural production is not only to increase the gross harvest of fruits and vegetables, but also the sale of products at the best price. In this regard, it is necessary to pay special attention to the post-harvest processing of fruits and vegetables, to create conditions for storage, to extend the period of sale and processing. To create conditions for stable storage of products with the minimum possible quality losses, it is necessary to introduce new and more advanced storage technologies from a technological and economic point of view.The article presents the results of the use of Kulantau vermiculite to preserve the quality characteristics of fruits and vegetables in the southern region of Kazakhstan.

Keywords:agricultural production, deodorization, distillation,vermiculite, modern technology.

\section{INTRODUCTION}

The creation and preservation of the quality characteristics of the fruit during their storage is provided mainly by the method and mode of storage, method of fruit placement and other technological factors.

Technological factors play a decisive role in the justification of methods of storage of products. Stabilization of temperature and humidity, application of packaging and use of controlled gas media are particularly important. An obligatory measure should be monitoring compliance with sanitary and hygienic conditions of storage. Technological measures during transportation and storage are determined by a set of quality indicators for each type of product.

Quality management systems in the storage of fruit and vegetable products are becoming more common and have broad prospects for implementation. [1-3].

Indicators of the quality of the fruit naturally affect their storage. The paper substantiates the possibility and necessity of variation of technological factors to create the most favorable conditions that support the quality of fruits and vegetables during their storage.

\section{MATERIAL AND METHOD}

The object of research is the comparative characteristic of indicators of quality of fruit and vegetables processing modes of storage when using kulantau vermiculite.

In the analysis of food and biological value in short-, medium - and long-term storage of each type of food was selected $10 \pm 0.1 \mathrm{~kg}$ of plant products. Samples for the study were selected about the same size, shape and weight. Evaluation of food and biological value of crop products was carried out under different treatment modes of ozone-air mixture. The organoleptic properties of the products were determined in raw form or after heat cooking in accordance with the requirements[3]. 5].

Qualitative characteristics of vermiculite Kulantau deposits were determined according to known methods[4- 


\section{RESULTS AND DISCUSSION}

Fruits belong to the group of vegetable juicy raw materials, so the main reasons for the loss of mass of juicy products are associated with the processes of respiration and evaporation [1]. The complex of measures on preservation of the harvest fruit and vegetable crops should take into account such phenomena as the processes of post-harvest ripening, the evaporation of moisture from the cells of fruits and vegetables, the actions of pests and temperature fluctuations. Modern technologies of organization of the most suitable storage conditions for juicy products are reduced to its cooling, moistening and disinfection, but the ways to achieve optimal storage parameters can have serious differences between themselves, and as a result, different efficiency[1-3].

Thus, the terms of storage of plant raw materials are established depending on the characteristics of the crop and varieties, terms and methods of harvesting, post-harvest processing and equipment of storage with automatic systems for creating and controlling the microclimate.

Since fruits and vegetables are stored fresh, before being placed for storage, these products must undergo certain processing, and the storage process must comply with scientifically sound rules.

Modern fruit and vegetable storage systems differ from their predecessors by full automation. Specially developed software regulates the operation of the entire system and, depending on the type of products stored and the set temperature, humidity and gas composition of the environment, automatically monitors the parameters of all equipment in order to create and maintain optimal conditions in the storage chambers.

The key points in the storage of fruits and vegetables are: temperature, relative humidity, disinfection.

Table 1 presents some parameters of storage of vegetables and fruits in the southern region.

According to table 1, it follows that for the proper storage of fruits and vegetables, specific conditions must be observed.

The existing technologies do not provide long-term preservation of products, and the loss of products due to moisture evaporation and consumption of dry substances for respiration, as well as due to the impact of bacterial and fungal micro flora in some cases reach $40-50 \%$. In addition, the rest of the products have reduced food quality and poor presentation [2-3].

TABLE I. Some parameters of storage of vegetables and fruits

\begin{tabular}{|l|l|c|c|}
\hline № & \multicolumn{1}{|c|}{ Product } & Storagetemperature, $\mathbf{C}^{\circ}$ & Relativehumidity, $\%$ \\
\hline 1 & Potato & $+3 \ldots+4$ & $85-93$ \\
\hline 2 & Cabbage & $0 \ldots+2$ & $84-88$ \\
\hline 3 & Onion & $+1 \ldots+7$ & $75-85$ \\
\hline 4 & Carrots & $0 \ldots+2$ & $88-96$ \\
\hline 5 & Radish & $0 \ldots+2$ & $92-95$ \\
\hline 6 & Beets & $0 \ldots+2$ & $9-96$ \\
\hline 7 & Cucumbers & $+6 \ldots+11$ & 93 \\
\hline 8 & Tomatoes & $+2 \ldots+5$ & $84-96$ \\
\hline 9 & Apricots & $0 \ldots+2$ & $93-96$ \\
\hline 10 & Watermelons & $+1 \ldots+2$ & $88-92$ \\
\hline 11 & Melons & $0 \ldots+2$ & $87-91$ \\
\hline 12 & Pears & $0 \ldots+2$ & 92 \\
\hline 13 & Apples & $0 \ldots+2$ & $84-94$ \\
\hline 14 & Lemons & $+1 \ldots+3$ & $83-90$ \\
\hline 15 & Peaches & $0 \ldots+2$ & $84-94$ \\
\hline
\end{tabular}

Biological factors that form and maintain the quality of the fruit: keeping quality, climatic conditions, agricultural conditions, the quality of products that are laid on storage, technological factors that create optimal conditions that ensure the preservation of quality characteristics of fresh fruits within a certain period.

The main means for regulating the physiological and biochemical processes that occur in fruits during storage is temperature.

According to the method of temperature control distinguish non-cooled and cooled storage methods.

Non-cooling methods are storage in stationary storage, where the maintenance of temperature and humidity is due to natural or forced ventilation, as well as drilling or trench storage.

Cooling methods are storage of fruits in cold rooms using various cooling systems.

According to the method of placing products in the store, storage can be bulk and tar. 
For storage of carrots in boxes a bottom pour wet sand, on it stack root crops in several layers and interlayer them with sand. Another modernized method of root crops storage is the use of polyethylene bags with a capacity of $20-25 \mathrm{~kg}$. Containers are not tied to avoid concentration of carbon dioxide and increase of relative humidity of the air [2].

Fruit products are stored in containers, where additional equipment is installed: gas generators, air sensors, adsorbers. This equipment is controlled by special programs, which allows to automatically create and maintain in a chamber with a low oxygen content and control the level of ethylene and carbon dioxide affecting the biochemical processes in the product [3].

In recent years, the scope of application of exfoliated vermiculite in agriculture increases sharply, with about one third of the total produced in the world, vermiculite is used in agriculture: vegetable production, horticulture, animal husbandry, veterinary science, and hydroponics, with the pelleting of seeds and the storage of vegetables and fruits.

There are deposits of vermiculite in our Republic. In the Turkestan region -deposits of Kulantau, Zhylandy, IDRs, etc. the Need of the Republic of Kazakhstan in the vermiculite can be tens of thousands of tons per year, thanks to the wide range of applications [4].

Qualitative characteristics of vermiculite Kulantau field are shown in table 2 .

Table 2 - Qualitative characteristics of vermiculite Kulantau field

Bulk volume mass, $\mathrm{kg} / \mathrm{m} 3$ 80-200

Coefficient of thermal conductivity at $25^{\circ} \mathrm{C}, \mathrm{W} / \mathrm{m}$ degree $0.048-0.060$

The coefficient of sound absorption at a frequency of $1000 \mathrm{~Hz} 0.7-0.8$

Melting point, ${ }^{\circ} \mathrm{C}+1250$

Application temperature, ${ }^{\circ} \mathrm{C}-260$ to +1200

The study of the properties kalantaevskogo of vermiculite has led to the conclusion that the use of vermiculite:

improves the structure of light (sandy) and heavy (clay and loam)

* optimally adjust the air-humidity mode;

* actively stimulates the growth of the root system and the plant as a whole;

- reduce the acidity and salinization of soil non-replaceable in the $8-14 \%$;

* increases the efficiency of fertilizers;

* reduces root rot disease;

* increases the safety of fruits and vegetables by $10-16 \%$;

* increases productivity by $12-17 \%$.

Exfoliated vermiculite is little hygroscopic, if moisture content $40-60 \%$ moisture content is $6-8 \%$, with $100 \%$ - no more than 10-11\%. In addition, it has a high adsorption capacity in relation to various products of fruit gas exchange. These features allow the use of exfoliated vermiculite to store vegetables, fruits and flower bulbs. It is absolutely sterile, environmentally friendly material with the highest sorption properties.

Due to its highly porous structure, vermiculite granules instantly take water and dissolved fertilizers, keep them and give them to plants gradually. Vermiculite has a high cation-exchange and catalytic properties. Magnesium, calcium, potassium and sodium ions are present in vermiculite in an easily accessible form. The ability of vermiculite to retain not only water but also air makes vermiculite highly effective conditioner of all soil types. Exfoliated vermiculite is a Golden-yellow granules obtained by instant heating of the natural mineral to 800 .

In addition to all the above, this mineral is perfect for storing fruit and vegetable crops. Such vermiculite functions as low hygroscopicity and absorption make it suitable for this. At $60 \%$ humidity mineral moisture is only $6-8 \%$, and at $100 \%$ humidity $-10-11 \%$ because of this, it is suitable for storage of the crop. High absorption properties do not allow the fruits and bulbs of plants to rot and deteriorate. At the same time, the taste of products and their nutritional value are not lost. For storage, you need to pour the fruit with vermiculite layer from 2 to $5 \mathrm{~cm}$, the thickness of the layer depends on the size of the fruit.

This reduces the level of waste that occurs in the case of rot development, slows down the growth processes in the tubers, and preserves the taste and nutritional value of vegetables and fruits. Pouring fruits at tare and unpacked storage it is possible to keep a harvest, having provided itself for a long time with tasty, healthy and useful products. Vegetables or fruits are laid in boxes in layers, shifting each row of fruits with a layer of expanded vermiculite, the thickness of which, depending on the size of the fruit varies from 2 to $5 \mathrm{~cm}$ in the second year, the used vermiculite can be used after roasting. 
Processing technology consisted of the following stages: pre-processing of storage and equipment, processing of products during storage, systematization of the results.

Fruit and vegetable products were stored in separate (for each mode) basement (warehouse) premises. The dimensions of the premises were from 200 to $250 \mathrm{~m}^{3}$. For the best access of gas to the products inside the premises, racks with a distance from the walls of $0.2-0.3 \mathrm{~m}$, between the rows and at a height of $0.5-0.6 \mathrm{~m}$ were equipped.Containers with food were installed on racks at a height of $0.2-0.3 \mathrm{~m}$ from the floor.

Plant products were placed in storage, depending on the processing mode. Up to 20-30 tons of food (about 56 tons of potatoes, cabbage, carrots, onions) were stored in the storages. Cabbages were placed on pallets on each other no more than in two rows. The rest of the products were stored in perforated plastic boxes in layers not exceeding $0.30-0.35 \mathrm{~m}$.

The ozonizers were placed in a separate room adjacent to the storage facilities of the products to which they were connected by an air duct system. The outlets of the air ducts in each room were equipped with manually operated dampers. The ozone-air mixture was fed to the upper third of the room every hour for 15 minutes.After reaching a concentration of $30-35 \mathrm{mg} / \mathrm{m}^{3}$, the units were turned off for 45 minutes. 3 -fold processing of products was carried out for 3 hours [4]. The experimental group of products was treated with ozone-air mixture in experimental modes: mode 1-daily; mode 2-2 times a week; mode 3-1 times a week; mode 4-2 times a month; mode 5-1 times a month; mode 6-1 times for the entire period of storage. Control samples of food were not processed by ozone and stored at a temperature of $12-16^{\circ} \mathrm{C}$ and relative humidity of $60-80 \%$. Microclimatic conditions of storage - temperature and humidity of experimental groups of products did not differ from those for the control group. Given the high oxidizing activity of ozone, it is impossible to exclude its possible adverse effect on the organoleptic properties and chemical composition of products in various technological modes of their storage, which can lead to a decrease in their nutritional and biological value [5].

In this regard, studies have been conducted on the effect of ozone-air mixture on the nutritional, biological value and quality of plant products: potatoes, cabbage, carrots, onions, apples.

In the process of food storage can be significant changes in the chemical composition, especially in the content of vitamins. In this regard, in order to justify the optimal storage and transportation of food, moisture, protein, starch, carbohydrates, vitamin $\mathrm{C}, \beta$-carotene were determined in them.

The results of studies on the preservation of food products have shown that the promising modes of storage of potatoes in order to preserve the biological value of this product are the modes of processing 2-4 times a month when laying vegetables for medium-term storage in warehouses with vermiculite (up to 3 months), and when storing potatoes for a longer time, more frequent processing may be recommended: 1-2 times a week.

\section{CONCLUSION}

Thus, the technological and economic justification of optimal modes of food processing with ozone-air mixture and the use of kulantau vermiculite provided the best preservation of fruits and vegetables.

The organization of proper storage of vegetables, root vegetables, potatoes and fruit when using kulantau vermiculite has a positive effect on different sectors: economy, sustainable production, local materials, business, and most importantly human health. It is obvious that modern storage techniques only improve the quality of products, which makes them popular in a highly competitive environment.

\section{REFERENCES}

[1] Syrmanova, K.K.; Kaldybekova, Zh.B. Polyfunctional sorbents. Monograph.168, 2012

[2] Karyakina, M.I. Testing of paint and varnish material. Chemistry.272, 2008

[3] Gerasimenko, A.A. Corrosion and aging protection of equipment and buildings. Handbook.784,2007

[4] Sanzharovskiy, A.T. Physical-chemical properties of polymeric and coating compositions.Chemistry. 184,1978

[5] Tuleuov, A.M.; Syrmanova, K.K.; Kaldybekova, Zh.B. About the features of metal preparing for coatings. Proceedings of international scientific-practical conference "New work in science: Strategy of sustainable development of regions' economics.197-202. 2014 


\section{AUTHOR PROFILE}

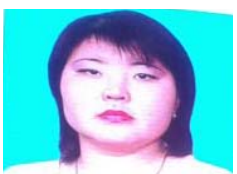

KaldybekovaZhanatBaizhanova (12.06.1978). In 2009 she defended her thesis. Candidate of technical Sciences, associate Professor of "Technology and food safety". Kaldybekova J. B. has over 100 publications and patents, the author of textbooks and manuals. Research area: adsorption, food engineering.

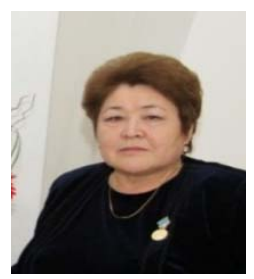

Syrmanova Kulash Kerimbaevna (03.01.1954). Engineer-chemist-technologist (1975). In 1984 she defended her thesis in Almaty. In 1997 she defended her doctoral dissertation in Moscow. Doctor of technical Sciences. Professor K. K. Syrmanova has over 300 scientific publications and patents, the author of textbooks and manuals, is a supervisor of masters and doctoral students, several grant projects.

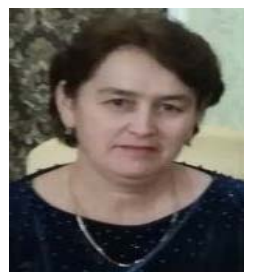

KhamitovaBarnaMahmutovna (28.04.1971). Engineer-chemist-technologist. In 2008 she defended her thesis, candidate of technical Sciences, associate Professor of the Department "Technology and food safety" of M. Auezov South Kazakhstan state University. Khamitova has more than 150 scientific and methodological works and patents, the author of textbooks and teaching AIDS, is the scientific supervisor of master's degree students. Scientific direction-resource-saving technology based on secondary raw materials of the food industry.

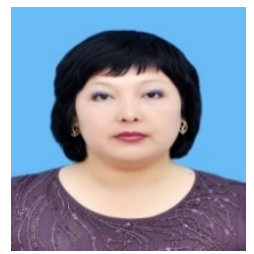

TaspoltayevaAibalaRysbekovna (27.01.1969). In 2010 she defended her thesis. Candidate of technical Sciences, associate Professor. Tashboltaev A. R. has more than 80 publications and patents, and author of textbooks and monographs. He is a research fellow of grant projects. Research area is chemical and food technology.

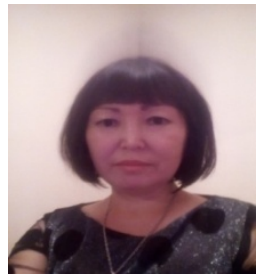

UngarbaevaAisuluSeylhanovna (24.08.1978). In 2004, she graduated from the international Kazakh-Turkish University named after H. A. Yassavi with the qualification of teacher of chemistry and biology. In 2007, she graduated from the University with a master's degree in Chemistry. Works as a senior lecturer at the Department of Chemistry and biology of Miras University. Scientific direction chemical kinetics. 